\title{
Postnatal development of the mucosal immune system and consequences on health in adulthood
}

Article

Published Version

Lewis, M., Inman, C. F. and Bailey, M. (2010) Postnatal development of the mucosal immune system and consequences on health in adulthood. Canadian Journal of Animal Science, 90 (2). pp. 129-136. ISSN 1918-1825 doi: https://doi.org/10.4141/CJAS09112 Available at https://centaur.reading.ac.uk/33292/

It is advisable to refer to the publisher's version if you intend to cite from the work. See Guidance on citing.

To link to this article DOI: http://dx.doi.org/10.4141/CJAS09112

Publisher: Agricultural Institute of Canada

All outputs in CentAUR are protected by Intellectual Property Rights law, including copyright law. Copyright and IPR is retained by the creators or other copyright holders. Terms and conditions for use of this material are defined in the End User Agreement.

www.reading.ac.uk/centaur 
Central Archive at the University of Reading

Reading's research outputs online 


\title{
Review: Postnatal development of the mucosal immune system and consequences on health in adulthood
}

\author{
M. Lewis, C. F. Inman, and M. Bailey \\ Clinical Veterinary Science, University of Bristol, Churchill Building, Langford House, Langford, UK BS40 5DU. \\ Received 24 November 2009, accepted 27 January 2010.
}

\begin{abstract}
Lewis, M., Inman, C. F. and Bailey, M. 2010. Postnatal development of the mucosal immune system and consequences on health in adulthood. Can. J. Anim. Sci. 90: 129-136. The intestinal microbiota is a dynamic multifaceted ecosystem which has evolved a complex and mutually beneficial relationship with the mammalian host. The contribution to host fitness is evident, but in recent years it has become apparent that these commensal microorganisms may exert far more influence over health and disease than previously thought. The gut microbiota is implicated in many aspects of biological function, such as metabolism, angiogenesis and immune development: disruption, especially during the neonatal period, which may impose life-long penalty. Elimination of the microbiota appears difficult, but manipulation of the ratios and dominance of composite populations can be achieved by alterations in diet, rearing environment, antibiotics and/or probiotics. Components of the intestinal microbiota are frequently documented to affect normal function of the mucosal immune system in experimental animals and in domesticated, agricultural species. However, it is not always clear that the effects described are sufficiently well understood to provide a sound basis for commercial intervention. Some microbial interventions may be beneficial to the host under particular circumstances, while detrimental during others. It is essential that we further our understanding of the complex and intricate host-commensal relationship to avoid causing more longterm damage than advantage.
\end{abstract}

Key words: Postnatal immune development, microbiota manipulation

\begin{abstract}
Lewis, M., Inman, C. F. et Bailey, M. 2010. Développement postnatal du système immunitaire muqueux et conséquences pour la santé de l'adulte. Can. J. Anim. Sci. 90: 129-136. La microflore intestinale est un écosystème dynamique à facettes multiples qui se caractérise par des relations complexes et mutuellement bénéfiques pour les unicellulaires et le mammifère qui les héberge. Son apport à la santé de l'hôte est manifeste, mais, ces dernières années, on s'est rendu compte que ces microorganismes commensaux exercent parfois une plus grande influence sur la santé et la maladie qu'on le croyait jusqu'alors. La microflore intestinale participe à de nombreux aspects du fonctionnement de l'organisme, notamment au métabolisme, à l'angiogenèse et au développement ou à la perturbation de l'immunité, surtout durant la période qui suit la naissance, ce qui peut avoir de lourdes conséquences le reste de la vie. Supprimer la microflore paraît difficile, mais on pourrait modifier les rapports et la dominance de certaines populations par l'alimentation, par l'environnement et par l'usage d'antibiotiques ou de probiotiques. On lit souvent que certaines composantes de la microflore intestinale affectent le fonctionnement normal du système immun muqueux chez les animaux de laboratoire ainsi que chez les animaux d'élevage, en agriculture. Malheureusement, les effets décrits ne sont pas toujours assez bien compris pour servir de base solide à une stratégie commerciale. L'intervention de certains microorganismes pourrait s'avérer bénéfique à l'hôte dans des circonstances précises, mais lui nuire dans d'autres situations. Il est capital qu'on en apprenne davantage sur ces complexes relations commensales avec l'hôte pour ne pas causer de dommages qui persisteront longtemps au lieu des bienfaits escomptés.
\end{abstract}

Mots clés: Développement postnatal du système immunitaire, manipulation de la microflore

\section{COLONISATION OF THE GASTROINTESTINAL TRACT}

Most host-microbe relationship studies have focused on host-pathogen interactions, as these often produce obvious phenotypes, which allow us to study the pathogenesis of disease. However, more recent studies indicate that the commensal microorganisms resident in the gut may have more influence over host health and disease than previously thought (Kelly et al. 2007). It is estimated that $90 \%$ of the cells in and on the body of adult mammals are composed of unicellular organisms, the majority of which are contained within the gastrointestinal tract. Collectively, these are referred to as the microbiota (Savage 1977) and contain 100 times more genes than the human genome (Hsiao et al. 2008). Bacteria are the predominant group, and account for in excess of 1000 different species (Eckburg et al. 2005). However fungi, protozoa, yeast and bacteriophages are frequent components of this complex ecosystem, which comprises diverse microenvironments along its length, resulting in varied species-distribution (Mackie et al. 1999).

Abbreviations: DC, dendritic cell; Peyer's patches; GF, germ free; Ig, immunoglobulin; ILF, isolated lymphoid follicles; MAMP, microbial associated molecular patterns; SFB, segmented filamentous bacteria 
The newborn mammalian gut is sterile, but colonisation with numerous bacterial species occurs rapidly following birth (Krishnan and Ramakrishna 1998). The species and order of colonisation is dependent on a number of factors including environment, nutrition, delivery mode and the use of prophylactic antibiotics (Kirjavainen and Gibson 1999). At present, our understanding of microbial colonisation of the neonatal gut is restricted to those bacteria which are culturable in the laboratory. More recently, 16S rDNA sequencing techniques have been applied to established microbiota of many species, but have not yet been used to determine the pattern of early colonization (Biasucci et al. 2008). However, the recent development of high-throughput sequencing using instruments such as the Illumina Genoma Analyzer will allow rapid microbial DNA analysis, and this will verify the stages of microbiota establishment under varying influencing conditions (Lazarevic et al. 2009). The evidence we do have reveals that typically, normal facultative anaerobic faecal bacteria include genera such as Bifidobacterium (Bullen et al. 1976) Escherischia, Klebsiella and Enterobacter (Yoshioka et al. 1983) are the first to establish in the gastrointestinal (GI) tract. However, if these species are not circulating in the immediate environment in sufficient quantities, or if antibiotics are in use, atypical initial seeding may occur, often by bacteria from the genera Bacteroides, Clostridium or by contaminating skin bacteria such as Staphylococcus (Kelly et al. 2007). Although the immediate consequences of colonisation with atypical microbiota are unclear, human infants carrying high levels of alpha-hemolytic group B Streptococcus are at increased risk of developing septicaemia (Persson et al. 1986). As the neonatal gut becomes an increasingly anaerobic environment, the early colonizers are progressively replaced until obligate anaerobes, from genera such as Bacteriodes, Eubacterium, and Fusobacterium, dominate the microbiota (Tlaskalova-Hogenova et al. 2004). During the first few weeks of life, microbial succession in the intestinal tract of chickens, pigs, cattle and humans is surprisingly similar (Smith 1965) at the phylum and genus levels, despite varying levels of microbial exposure. Changes in the gut microbiota continue over time (Ellis-Pegler et al. 1975) until it becomes sufficiently stable to make colonisation by and proliferation of new strains and species difficult (Adlerberth and Wold 2009).

\section{INTERACTIONS BETWEEN INTESTINAL MICROBIOTA AND THE IMMUNE SYSTEM}

\section{Function of the Mucosal Immune System}

Clearly, the largest interface between an organism and its environment is the intestinal tract mucosa, which is also a potential site of entry for invading bacteria. To deal appropriately with these potentially damaging pathogens, the gastrointestinal tract is rich in immunological cells associated with both the adaptive and innate immune system, located in the organized lymphoid tissue of the Peyer's patches, isolated lymphoid follicles and mesenteric lymph nodes, and, also, more diffusely in and below the epithelium (Artis 2008). However, a healthy host must be able to differentiate between these putative pathogens and antigens from food and from the resident commensal bacteria, to find a balance between immunity and tolerance. Dysregulation of this balance is one proposed aetiology of inflammatory bowl diseases such as ulcerative colitis and Crohn's disease in humans (Karin et al. 2006).

Although protected to a degree by secreted IgA, the apical surface brush border of the gut epithelial cells is in intimate contact with the intestinal microbiota (Shen and Turner 2006). Since the presence of pathogens appears to be detected rapidly, it has been postulated that luminal contents are under constant surveillance by the host immune system (Coombes and Powrie 2008). The subepithelial domes of the Peyer's patches and lymphoid follicles contain specialized dendritic cell (DC) subsets, which are shielded by the follicle-associated epithelium (Fig. 1). This specialized epithelium contains M (microfold)-cells (Chirdo et al. 2005). Food antigen and bacterial products traverse these specialized cells via transcytosis and are taken up and processed by the underlying DCs, which express a wide range of pattern recognition receptors (PRR) (Milling et al. 2005). These receptors, expressed primarily by host immune cells, recognize microbial-specific molecular patterns, such as unmethylated $\mathrm{CpG}$ motifs and manose residues, allowing the host to differentiate between harmless food antigen and potential pathogens. When the presentation of processed antigen by DCs to T-lymphocytes results in an active immune response, the T-lymphocytes differentiate down various pathways, which ultimately result in the appropriate immune response. These alternate differentiation pathways have been well studied in mice and humans, but less so in domestic species. Fully differentiated, effector T-lymphocytes have been categorized into four subsets: T-helper-1 (Th1), characterized by secretion of the cytokine interferon- $\gamma$ and involved primarily in responses to intracellular pathogens such as viruses, coccidian protozoa and Salmonella; a Th2 phenotype secreting interleukin-4, involved in responses to extracellular pathogens such as nematode infections; Th17, secreting interleukin-17 and involved in acute inflammatory responses specifically to bacterial and fungal pathogens; and regulatory T-cells or Tregs, characterised by their production of TGF $\beta$ and/or IL10, capable of limiting responses by other T-cells (Sallusto and Lanzavecchia 2009). All of these subsets tend to promote differentiation of further T-cells down the same pathway, by positive feedback. In addition, Treg cytokines also act to suppress the function of pre-differentiated Th1 and Th17 T-cells. This delicate balance ensures tight control over responses to antigens crossing through the epithelium; however, a bias in either direction may result in an inappropriate response 


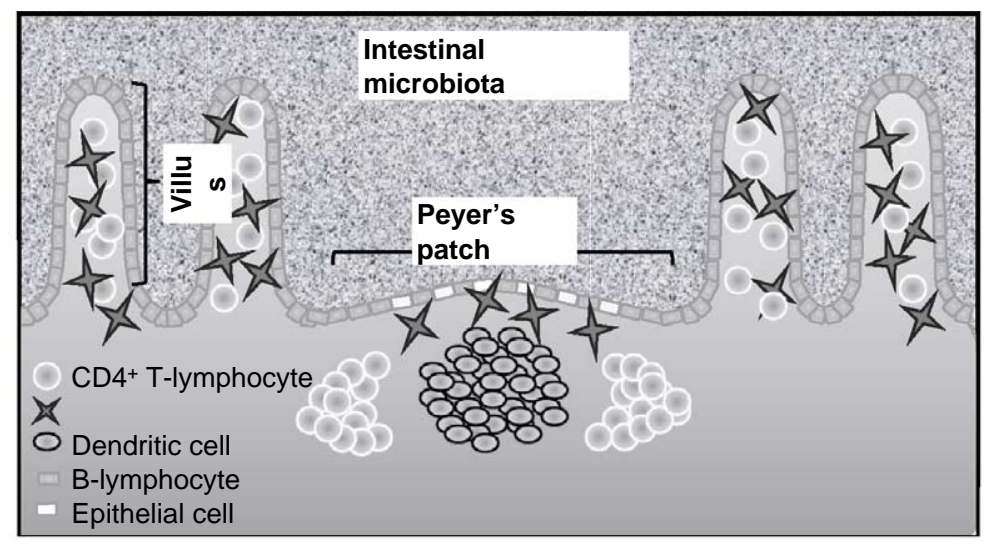

Fig. 1. Organisation of immune cells within the intestine. Commensal and pathogenic bacteria and food antigens can cross the epithelium of the intestinal villi or be taken up into Peyers patches via the M-cells. Underlying dendritic cells transport antigen to the T-cell zone of the Peyers patch or to the mesenteric lymph nodes, where they present specific antigen to CD $4+\mathrm{T}$-cells. The outcome of presentation (Th1/Th2/Th17/Treg) is dependent on the extent to which dendritic cells have been concurrently activated by bacterial MAMPs.

occurring. In normal animals, responses to food antigens (e.g., soya or egg proteins in pigs) are actively suppressed (Bailey et al. 2004), and this active suppression of immune responses may also apply to antigens of the commensal microbiota. Cells of the innate immune system recognize microbes via molecular motifs unique to, and conserved between, groups of bacteria (Didierlaurent et al. 2005). These microbial associated molecular patterns (MAMPs), are constructed from bacteria-specific peptidoglycan and lipopolysaccharide components of the cell envelope (Chen and Nunez 2009). How discrimination between pathogen and commensal microbiota is achieved is unclear, as both groups share similar conserved MAMPs. Presumably, discrimination involves direct detection of tissue damage associated with pathogen, indicating "danger", but the mechanisms by which this is achieved remain to be determined.

\section{THE EFFECTS OF THE MUCOSAL IMMUNE SYSTEM ON NORMAL MICROBIOTA}

Despite its benefit to the host, the intestinal microbial community must live with continual pressure from the mucosal immune system at some level. For example, secretion of immunoglobulin (Ig) A across the intestinal epithelium affects the intestinal microbiota. Studies in mice deficient in secreted polymeric IgA due to J-chain deletion, or those which are IgA deficient due to $\mathrm{C}$-alpha gene deletions, exhibit increased levels of antibody to dietary proteins (Cunninghamrundles et al. 1978) and an expansion of unusual species of small gut microbiota (Fagarasan et al. 2002), especially segmented filamentous bacteria (SFB) (Suzuki et al. 2004). In mice reconstituted with the ability to produce normal levels of IgA, the prolific SFB population retreats back to the large intestine and the composition of the small intestinal microbiota comes to resemble that of a normal animal (Suzuki et al. 2004). Similarly, the specificity of antimicrobial peptides such as the cryptidins is not sufficient to distinguish pathogen from commensal (Ouellette 1997).

\section{COMMENSAL BACTERIA DRIVE IMMUNE DEVELOPMENT}

The evolution of host and non-pathogenic gut-microbiota have occurred co-dependently and this has resulted in intricate and integrated symbiotic relationships existing between the two. The host provides a multitude of microenvironments and niches, whilst the microbiota have been shown to benefit the host in numerous ways. The commensal microorganisms reduce pathogenic colonisation (Falk et al. 1998) by providing the first line of defence against, and competing with, invading organisms (Stecher and Hardt 2008). In addition, certain elements of the microbiota play a critical role in nutrient absorption (Hooper et al. 2002) while others biosynthesize essential products such as vitamins $B_{12}$ and $\mathrm{K}$, which the host is unable to generate in its absence (Hooper et al. 1998). It is even becoming clear that the microbiota influence such complex processes as lipid (Backhed et al. 2004a) and carbohydrate (Underwood et al. 2009) metabolism by the host (Backhed et al. 2004b) and tissue repair (Thompson-Chagoyán et al. 2005) and angiogenesis (Bjorkholm et al. 2009). Perhaps one of the most intriguing capacities of these microorganisms is to drive the development of the neonatal humoral and cellular immune systems (Carter and Pollard 1971). This is evident in mammals and birds reared in the absence of microbes. Postnatal development of the mucosal immune system in domestic species has been reviewed elsewhere (Bailey and Haverson 2006), and the evidence from "germ-free" (GF) and gnotobiotic animals is that much of the development is driven by commensal microbiota. These GF animals fail to generate competent and effective immune defences 
and gut morphology and physiology are altered (Butler et al. 2000). Lymph nodes, isolated lymphoid follicles and Peyer's patches germinal centres are underdeveloped and contain reduced $\mathrm{CD}^{+}$and $\mathrm{CD}^{+}{ }^{+} \mathrm{T}$ lymphocyte populations (Cebra et al. 1998) and limited numbers of myeloid and lymphoid cells (especially $\operatorname{IgA}$ plasmablasts) are present in the lamina propria (Cebra 1999). The role of commensal bacteria is demonstrated by the addition of microbes to previously GF animals (Talham et al. 1999). Monocolonisation of gnotobiotic animals with SFB, in particular, has been shown to increase IgA-secreting and lymphoid cell populations in caecal and ileal lamina propria (Meyerholz et al. 2002).

\section{MANIPULATION OF MICROBIOTA AND EFFECTS ON DISEASE SUSCEPTIBILITY}

The gut-associated microbiota in mice and humans cluster within many phyla, but $90 \%$ belong to Firmicutes or Bacteriodetes bacterial division (Ley et al. 2005). The remaining 10\% include Proteobacteria, Actinobacteria, Verrucomicrobia and Cyanobacteria bacterial divisions. Although contributions at the phylum level are fairly consistent between humans and mice, interindividual species variation is high (Gill et al. 2006). The importance and benefits of the gut microbiota to the host are clear and this raises the question of what the consequences to the host are, when gut microbiology is altered. This could be indirectly due to fluctuations in influencing factors, or directly by elimination or introduction of species novel to this unique ecosystem. Many diseases have been linked to fluctuations in the various bacterial populations comprising the microbiota, from inflammatory bowel disease and colorectal cancers to obesity (Sekirov et al. 2008). However, It should be noted that it is not clear from these studies whether the disease is a consequence of the intestinal microbiota or vice versa.

Perhaps the most obvious form of intervention, and one which has been widely practiced in agriculture by the use of growth promoters, is administration of antimicrobial agents. It might be assumed that treatment with antibiotics would eliminate all members of the microbial community for the duration of treatment. However, it should be remembered that a proportion of the community is comprised of non-bacteria microbes and a section of the bacterial species present will not be susceptible to a particular mode of action of specific antibiotic therapies. Traditionally, analysis of gut microbiota was achieved using culturing techniques. However since the development of 16S rRNA sequencing techniques in recent years (Suau et al. 1999), it has become apparent that culturable bacteria represent approximately $5 \%$ of the overall microbiota (Backhed et al. 2005). For this reason, it is not unreasonable to suggest that early studies using antibiotics may have appeared to eliminate the microbiota when they in fact merely purged the culturable bacterial species from the host intestinal tract. Furthermore, Croswell et al. tested a variety of antibiotic combinations which concurrently targeted Gram-positive, Gram-negative, anaerobic and aerobic species. Despite the administration method and mode of action of each antibiotic regiment varying considerably, only the culturable species could be eliminated from the murine gut: none of the combinations completely cleared the microbiota, only altered its composition. This may reflect the fact that all our current antibiotics have, inevitably, been developed and screened to target culturable bacteria involved in disease. Thus, although antibiotics will certainly affect disease susceptibility due to a direct effect on bacterial pathogens, they may have more subtle and long-term effects through their impact on the resident microbiota and its relationship with the mucosal immune system.

The consequences of antimicrobial treatments for the host are at least threefold. Firstly, selective environmental pressure leads to an increase in antibiotic resistant genes within the community, and these have the potential to transfer horizontally to pathogenic gut bacteria. The result is the development of a reservoir of virulent bacteria in animal and human hosts which are resistant to antimicrobial therapies (Sommer et al. 2009). Second, distortion of species diversity within an organism can result in overgrowth of resistant strains. This may occur either as a consequence of availability of niches caused by elimination of other species susceptible to the antibiotics, or as a result of indirect effects of the change in microbiota on immunological function, as in the Th17 studies described later. Well-known examples of microbes which lead to this situation occurring are the yeast Candida albicans and bacterial Clostridium difficile. Candida albicans is gut-indigenous and a potential pathogen of most animals if the population expands unchecked within the intestinal environment. Overgrowth following antibiotic therapy can lead to systemic infections and death of domestic and wild animals and birds (Buck 1990) and is one source of abortions in cattle (Foley and Schlafer 1987). Clostridium difficile is a ubiquitous commensal intestinal bacteria of mammalian gastrointestinal tracts. This Gram-positive anaerobic bacillus can cause acute colitis in mature horses and foals which have received antibiotic therapy (Baverud 2002). Over $50 \%$ of preweaning deaths of intensively reared calves is attributed to diarrhoea and over $40 \%$ of diarrheic calves tested positive for $C$. difficile during a recent survey (Hammitt et al. 2008). Clostridium difficile-associated disease also affects swine, humans (Surawicz 2009) and laboratory animals and can cause severe pathology (Songer and Anderson 2006). Incidents of Clostridium difficileassociated disease have been reported in humans after just one antibiotic dose. In these two examples, disease follows disruption of the commensal bacteria following antibiotic therapy, supporting the notion that microbial imbalance precedes disease. However, the reverse may be true in different circumstances. The third consequence of antibiotic therapy is increased susceptibility to 
pathogenic disease. This is apparent in the laboratory, where, in order to achieve consistent enteric infection in mouse models, it is not unusual to first perturb the microbiota using antibiotics (Croswell et al. 2009). Sekirov et al. (Sekirov et al. 2008) tested murine susceptibility to Salmonella enterica serovar Typhimurium after exposing mice for $48 \mathrm{~h}$ to increasing clinically realistic concentration of broad-spectrum streptomycin and vancomycin, which exhibit anti-Gram-positive activity. This regimen failed to reduce the total gut bacterial count, but did affect the composition of the microbiota at the species level. The team concluded that the greater the pre-infection perturbation of the microbiota, the more severe the pathology of the disease caused by this pathogen. In addition, post-infection modifications to the microbiota were greater in those mice exposed to higher concentration of antibiotics.

Probiotics are defined as "live microorganisms which when administered in adequate amounts confer a health benefit on the host" (FAO/WHO 2002). Usually administered orally in food products such as yoghurts, these bacterial species usually journey through, but rarely colonise, the intestinal tract and therefore persist only for the duration of consumption (Corthesy et al. 2007). The evidence suggests that for specified intestinal diseases, probiotic therapy does confer a health benefit on the host. For example, $12 \mathrm{wk}$ of treatment with Bifidobacterium-fermented milk was shown to significantly reduce the clinical activity index, endoscopic and histological scores in ulcerative colitis patients compared with a placebo (Kato et al. 2004). The specific mechanisms of action of probiotics remains elusive, but a number of hypotheses have been suggested, such as competitive inhibition of the growth or persistence of pathogens and of the binding of their toxins to intestinal epithelium. For example, several Bifidobacteria and Lactobacilli strains are known to out-compete enterotoxigenic Escherichia coli (Sherman et al. 2005) and Clostridium difficile (Collado et al. 2007) at the mucosal surface. Probiotics are also known to produce an array of antimicrobial substances active against pathogenic bacteria, from bacteriocins which target the lipid II component of the cell wall of multidrug resistant pathogens (Morgan et al. 2005) to narrow-spectrum highly divergent antimicrobial peptides which primarily target Gram-positive bacteria such as Listeria and Mycobacteria by creating pores in the membrane and interfering with essential enzyme activity (Makarova et al. 2006). In the gut, M-cells internalise probiotics which initiate immune responses by $\mathrm{B}$ - and T-lymphocytes through interactions with follicular and dendritic cells (Winkler et al. 2007). Upregulation may promote tumour and pathogen clearance, whilst down-regulation may subdue allergic and inflammatory responses (Vanderpool et al. 2008). What is not clear at this stage is whether probiotics exhibit their specific effects on the immune system independent of the existing microbiota, or in complex synergy and are therefore reliant on the presence of co-operators. Future rational development of novel, effective probiotics and therapeutic strategies will require a deeper understanding of the mechanism of action and the impact of probiotics on the existing microbiota.

It is also well documented that diet impacts on the microbiota and that a change in food types can lead to both transient and permanent changes in an otherwise stable microbiota (Noverr and Huffnagle 2004). Rearing environment has been shown to influence the microbiota in pigs, comparing outdoor-reared piglets on the sow with litter-matched animals maintained in very clean isolators and fed milk-replacer. Outdoor-reared piglets had much higher numbers of Lactobacillus spp. than those in isolators, and this was associated with changes in levels of a variety of imm'une-associated genes (Mulder et al. 2009). Th17 T-lymphocytes have been shown to be involved in the pathogenesis of inflammatory bowel disease in rodents and, possibly, in humans (Cooney and Jewell 2009), such that a change in the balance of effector (Th17) and Treg T-lymphocytes in the intestinal mucosa may have beneficial effects under some circumstances and adverse consequences under others. Differences in numbers of Th17 T-lymphocytes in the intestinal mucosa occur between mice of similar strains reared in different facilities. Th17 cells as a proportion of the total $\mathrm{CD} 4{ }^{+} \mathrm{T}$ cell population was between 10 and $15 \%$ in mice obtained from a number of commercial vendors. However, mice from one supplier consistently had LP Th17 T-cell levels which comprised only $1-2 \%$ of the overall $\mathrm{CD} 4{ }^{+} \mathrm{T}$ cell population (Ivanov et al. 2008). This difference is most likely driven by variations in diet and bacterial presence in the different environments, which, in turn, impacts on the intestinal microbiota. In more detailed studies, a specific SFB has been shown to drive Th17 accumulation in the mouse intestine, and to protect against infection with Citrobacter rodentium (Ivanov et al. 2009). In addition, SFB have been shown to largely recapitulate the coordinated maturation of Th1 and Tregs in the small intestine of gnotobiotic mice, to the same extent as that induced by the whole mouse microbiota (GaboriauRouthiau et al. 2009).

\section{THE IMPACT OF PROBIOTICS: BALANCING EFFECTOR AND REGULATORY FUNCTION}

As described, the evidence that components of the intestinal microbiota can have effects on normal function of the mucosal immune system in experimental animals and in domesticated, agricultural species is clear. However, it is less clear that the effects described are sufficiently well understood to provide a sound basis for commercial intervention. In the mouse system described, changes in microbiota resulted in a change in the ratio of Th17 and Treg cells at mucosal surfaces (Ivanov et al. 2008). Tipping the balance to Th17 in situations where pathogen challenge is the predominant problem may be an advantage, but such a change could result in a reduced ability to control immune responses 
to harmless fed antigens. Since this kind of "allergic" response to proteins in the diet occurs in weaned piglets and has been proposed to contribute to the aetiology of postweaning diarrhea, changing the Th17/Treg balance may be disadvantageous where enteric bacterial pathogens are less problematic (Bailey et al. 2004). Since Th1 and Th2 T-lymphocytes also occur in the intestinal mucosa, any influence of rearing environment and/or direct intervention in gut microbiota needs to take into account the effect on the balance of these subsets as well (Fig. 2). For example, since Th2 responses are particularly effective at clearing nematode infections, manipulation of the balance of T-lymphocyte subsets towards Th2 may be beneficial where diseases such as Ascaris infections are a major problem, providing the animals were not then exposed to infection with enteric Coccidian protozoa. In contrast, manipulation of the balance of T-lymphocytes in the intestinal mucosa towards Th1 might confer increased resistance to coccidia, but decreased resistance to Salmonella or Ascaris infection.

In future, it seems unlikely that one form of manipulation or probiotic will enhance performance under all systems of management. It seems much more likely that continuing work on the influence of different components of the natural microbiota or of novel species and strains administered as probiotics will identify the specific effects of each on the components of the mucosal immune system. Together with similar work on the importance of each of these components in resistance to enteric diseases, this will allow interventions designed to manipulate microbiota to optimize performance under different rearing conditions or in the face of particular pathogen challenges. This view of the

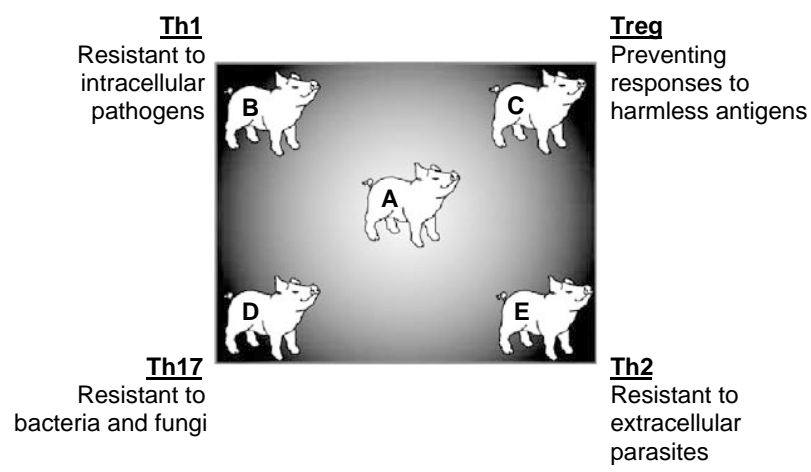

Fig. 2. Skewing the balance between different components of the mucosal immune response. Piglet A has a balanced immune system, capable of moderate responses to all types of pathogens (Th1, Th2, Th17) and of controlling unwanted responses to harmless antigens (Treg). Piglet $\mathrm{B}$ has increased ability to protect against intracellular pathogens such as Isospora, but reduced ability to deal with nematodes such Ascaris (th2), and has the possibility of mounting damaging responses to food antigens (Treg). Similarly, piglet $\mathrm{C}$ may avoid costly responses to food antigen, but will be highly susceptible to all infectious diseases, while piglet D may cope better with Salmonella infections but poorly with Ascaris. likely use of probiotics has interesting parallels with the use of antibiotics, which were originally seen as universal tools for disease control, but are now used in a much more targeted way, specific antibiotics being active in controlling particular diseases, and with the harmful effects of prolonged antibiotic treatment better recognized.

Adlerberth, I. and Wold, A. E. 2009. Establishment of the gut microbiota in Western infants. Acta Paediatr. 98: 229-238.

Artis, D. 2008. Epithelial-cell recognition of commensal bacteria and maintenance of immune homeostasis in the gut. Nat. Rev. Immunol. 8: 411-420.

Backhed, F., Ding, H., Wang, T., Hooper, L. V., Koh, G. Y., Nagy, A., Semenkovich, C. F. and Gordon, J. I. 2004a. The gut microbiota as an environmental factor that regulates fat storage. Proc. Natl. Acad. Sci. USA 101: 15718-15723.

Backhed, F., Ding, H., Wang, T., Hooper, L. V., Koh, G. Y., Nagy, A., Semenkovich, C. F. and Gordon, J. I. 2004b. The gut microbiota as an environmental factor that regulates fat storage. Proc. Natl. Acad. Sci. USA 101: 15718-15723.

Backhed, F., Ley, R. E., Sonnenburg, J. L., Peterson, D. A. and Gordon, J. I. 2005. Host-bacterial mutualism in the human intestine. Science 307: 1915-1920.

Bailey, M. and Haverson, K. 2006. The postnatal development of the mucosal immune system and mucosal tolerance in domestic animals. Vet. Res. 37: 443-453.

Bailey, M., Haverson, K., Miller, B., Jones, P., Sola, I., Enjuanes, L. and Stokes, C. R. 2004. Effects of infection with transmissible gastroenteritis virus on concomitant immune responses to dietary and injected antigens. Clin. Diagn. Lab. Immunol. 11: 337-343.

Baverud, V. 2002. Clostridium difficile infections in animals with special reference to the horse. A review. Vet. Q. 24: 203-219.

Biasucci, G., Benenati, B., Morelli, L., Bessi, E. and Boehm, G. 2008. Cesarean delivery may affect the early biodiversity of intestinal bacteria. J. Nutr. 138: 1796S-1800.

Bjorkholm, B., Bok, C. M., Lundin, A., Rafter, J., Hibberd, M. L. and Pettersson, S. 2009. Intestinal microbiota regulate xenobiotic metabolism in the liver. PLoS One 4: e6958.

Buck, J. D. 1990. Isolation of Candida-Albicans and halophilic Vibrio spp. from aquatic birds in Connecticut and Florida. Appl. Environ. Microb. 56: 826-828.

Bullen, C. L., Tearle, P. V. and Willis, A. T. 1976. Bifidobacteria in intestinal-tract of infants - in vivo study. J. Med. Microbiol. 9: 325.

Butler, J. E., Weber, P., Sinkora, M., Sun, J., Ford, S. J. and Christenson, R. K. 2000. Antibody repertoire development in fetal and neonatal piglets. II. Characterization of heavy chain complementarity-determining region 3 diversity in the developing fetus. J. Immunol. 165: 6999-7010.

Carter, P. B. and Pollard, M. 1971. Host responses to normal microbial flora in germ-free mice. J Reticuloendoth Soc. 9: 580 .

Cebra, J. J. 1999. Influences of microbiota on intestinal immune system development. Am. J. Clin. Nutr. 69: 1046S-1051.

Cebra, J. J., Periwal, S. B., Lee, G., Lee, F. and Shroff, K. E. 1998. Development and maintenance of the gut-associated lymphoid tissue (GALT): the roles of enteric bacteria and viruses. Dev. Immunol. 6: 13-18. 
Chen, G. Y. and Nunez, G. 2009. Gut immunity: A NOD to the commensals. Curr. Biol. 19: R171-R174.

Chirdo, F. G., Millington, O. R., Beacock-Sharp, H. and Mowat, A. M. 2005. Immunomodulatory dendritic cells in intestinal lamina propria. Eur. J. Immunol. 35: 1831-1840.

Collado, M. C., Meriluoto, J. and Salminen, S. 2007. Role of commercial probiotic strains against human pathogen adhesion to intestinal mucus. Lett. Appl. Microbiol. 45: 454-460.

Coombes, J. L. and Powrie, F. 2008. Dendritic cells in intestinal immune regulation. Nat. Rev. Immunol. 8: 435-446.

Cooney, R. and Jewell, D. 2009. The genetic basis of inflammatory bowel disease. Dig. Dis. 27: 428-442.

Corthesy, B., Gaskins, H. R. and Mercenier, A. 2007. Crosstalk between probiotic host immune system. J. Nutr. 137: 781s-790s.

Croswell, A., Amir, E., Teggatz, P., Barman, M. and Salzman, N. H. 2009. Prolonged impact of antibiotics on intestinal microbial ecology and susceptibility to enteric Salmonella infection. Infect. Immunol. 77: 2741-5273.

Cunninghamrundles, C., Brandeis, W. E., Good, R. A. and Day, N. K. 1978. Milk precipitins, circulating immune-complexes, and Iga deficiency. Proc. Natl. Acad. Sci. USA 75: 3387-3389. Didierlaurent, A., Simonet, M. and Sirard, J. C. 2005. Innate and acquired plasticity of the intestinal immune system. Cell. Molec. Life Sci. 62: 1285-1287.

Eckburg, P. B., Bik, E. M., Bernstein, C. N., Purdom, E., Dethlefsen, L., Sargent, M., Gill, S. R., Nelson, K. E. and Relman, D. A. 2005. Diversity of the human intestinal microbial flora. Science 308: 1635-1638.

Ellis-Pegler, R. B., Crabtree, C. and Lambert, H. P. 1975. The faecal flora of children in the United Kingdom. J. Hyg. (Lond.) 75: $135-142$.

Fagarasan, S., Muramatsu, M., Suzuki, K., Nagaoka, H., Hiai, H. and Honjo, T. 2002. Critical roles of activation-induced cytidine deaminase in the homeostasis of gut flora. Science 298: 1424-1427.

Falk, P. G., Hooper, L. V., Midtvedt, T. and Gordon, J. I. 1998. Creating and maintaining the gastrointestinal ecosystem: What we know and need to know from gnotobiology. Microbiol. Mol. Biol. R. 62: 1157.

FAO/WHO. 2002. Joint FAO/WHO expert consultation on evaluation of health and nutritional properties of probiotics in food including powder milk with live lactic acid bacteria. FAO, Rome, Italy.

Foley, G. L. and Schlafer, D. H. 1987. Candida abortion in cattle. Vet. Pathol. 24: 532-536.

Gaboriau-Routhiau, V., Rakotobe, S., Lécuyer, E., Mulder, I. , Lan, A., Bridonneau, C., Rochet, V., Pisi, A., De Paepe, M., Brandi, G. and others. 2009. The key role of segmented filamentous bacteria in the coordinated maturation of gut helper T cell responses. Immunity 31: 677-689.

Gill, S. R., Pop, M., DeBoy, R. T., Eckburg, P. B., Turnbaugh, P. J., Samuel, B. S., Gordon, J. I., Relman, D. A., FraserLiggett, C. M. and Nelson, K. E. 2006. Metagenomic analysis of the human distal gut microbiome. Science 312: 1355-1359. Hammitt, M. C., Bueschel, D. M., Keel, M. K., Glock, R. D., Cuneo, P., DeYoung, D. W., Reggiardo, C., Trinh, H. T. and Songer, J. G. 2008. A possible role for Clostridium difficile in the etiology of calf enteritis. Vet. Microbiol. 127: 343-352.

Hooper, L. V., Bry, L., Falk, P. G. and Gordon, J. I. 1998. Host-microbial symbiosis in the mammalian intestine: exploring an internal ecosystem. Bioessays 20: 336-343.
Hooper, L. V., Midtvedt, T. and Gordon, J. I. 2002. How hostmicrobial interactions shape the nutrient environment of the mammalian intestine. Annu. Rev. Nutr. 22: 283-307.

Hsiao, W. W., Metz, C., Singh, D. P. and Roth, J. 2008. The microbes of the intestine: an introduction to their metabolic and signaling capabilities. Endocrinol. Metab. Clin. North. Am. 37: 857-871.

Ivanov, II, Atarashi, K., Manel, N., Brodie, E. L., Shima, T., Karaoz, U., Wei, D., Goldfarb, K. C., Santee, C. A., Lynch, S. V. and others. 2009. Induction of intestinal Th17 cells by segmented filamentous bacteria. Cell 139: 485-498.

Ivanov, II, Frutos Rde, L., Manel, N., Yoshinaga, K., Rifkin, D. B., Sartor, R. B., Finlay, B. B. and Littman, D. R. 2008. Specific microbiota direct the differentiation of IL-17-producing Thelper cells in the mucosa of the small intestine. Cell Host Microbe. 4: 337-349.

Karin, M., Lawrence, T. and Nizet, V. 2006. Innate immunity gone awry: linking microbial infections to chronic inflammation and cancer. Cell 124: 823-835.

Kato, K., Mizuno, S., Umesaki, Y., Ishii, Y., Sugitani, M., Imaoka, A., Otsuka, M., Hasunuma, O., Kurihara, R., Iwasaki, A. and others. 2004. Randomized placebo-controlled trial assessing the effect of bifidobacteria-fermented milk on active ulcerative colitis. Aliment Pharmacol. Ther. 20: 1133-1141.

Kelly, D., King, T. and Aminov, R. 2007. Importance of microbial colonization of the gut in early life to the development of immunity. Mutat. Res.-Fund. Mol. M 622: 58-69.

Kirjavainen, P. V. and Gibson, G. R. 1999. Healthy gut microflora and allergy: factors influencing development of the microbiota. Ann. Med. 31: 288-292.

Krishnan, S. and Ramakrishna, B. S. 1998. Butyrate and glucose metabolism in isolated colonocytes in the developing rat colon. J. Pediatr. Gastr. Nutr. 26: 432-436.

Lazarevic, V., Whiteson, K., Huse, S., Hernandez, D., Farinelli, L., Osteras, M., Schrenzel, J. and Francois, P. 2009. Metagenomic study of the oral microbiota by Illumina high-throughput sequencing. J. Microb. Meth. 79: 266-271.

Ley, R. E., Backhed, F., Turnbaugh, P., Lozupone, C. A., Knight, R. D. and Gordon, J. I. 2005. Obesity alters gut microbial ecology. Proc. Natl. Acad. Sci. USA 102: 11070-11075.

Mackie, R. I., Sghir, A. and Gaskins, H. R. 1999. Developmental microbial ecology of the neonatal gastrointestinal tract. Am. J. Clin. Nutr. 69: 1035s-1045s.

Makarova, K., Slesarev, A., Wolf, Y., Sorokin, A., Mirkin, B., Koonin, E., Pavlov, A., Pavlova, N., Karamychev, V., Polouchine, $\mathbf{N}$. and others. 2006. Comparative genomics of the lactic acid bacteria. Proc. Natl. Acad. Sci. USA 103: 15611-15616. Meyerholz, D. K., Stabel, T. J. and Cheville, N. F. 2002. Segmented filamentous bacteria interact with intraepithelial mononuclear cells. Infect. Immunol. 70: 3277-3280.

Milling, S. W., Cousins, L. and MacPherson, G. G. 2005. How do DCs interact with intestinal antigens? Trends Immunol. 26: 349-352.

Morgan, S. M., O'Connor, P. M., Cotter, P. D., Ross, R. P. and Hill, C. 2005. Sequential actions of the two component peptides of the lantibiotic lacticin 3147 explain its antimicrobial activity at nanomolar concentrations. Antimicrob. Agents Chemother. 49: 2606-2611.

Mulder, I., Schmidt, B., Stokes, C., Lewis, M., Bailey, M., Aminov, R., Prosser, J., Gill, B., Pluske, J., Mayer, C.-D. and others. 2009. Environmentally acquired bacteria influence 
microbial diversity and natural innate immune responses at gut surfaces. BMC Biology 7: 79.

Noverr, M. C. and Huffnagle, G. B. 2004. Does the microbiota regulate immune responses outside the gut? Trends Microbiol. 12: $562-568$

Ouellette, A. J. 1997. Paneth cells and innate immunity in the crypt microenvironment. Gastroenterology 113: 1779-1784.

Persson, K. M. S., Bjerre, B., Elfstrom, L., Polberger, S. and Forsgren, A. 1986. Fecal carriage of Group-B Streptococci. Eur. J. Clin. Microbiol. 5: 156-159.

Sallusto, F. and Lanzavecchia, A. 2009. Heterogeneity of CD4+ memory $\mathrm{T}$ cells: functional modules for tailored immunity. Eur. J. Immunol. 39: 2076-2082.

Savage, D. C. 1977. Microbial ecology of gastrointestinaltract. Annu. Rev. Microbiol. 31: 107-133.

Sekirov, I., Tam, N. M., Jogova, M., Robertson, M. L., Li, Y. L., Lupp, C. and Finlay, B. B. 2008. Antibiotic-induced perturbations of the intestinal microbiota alter host susceptibility to enteric infection. Infect. Immunol. 76: 4726-4736.

Shen, L. and Turner, J. R. 2006. Role of epithelial cells in initiation and propagation of intestinal inflammation. Eliminating the static: tight junction dynamics exposed. Am. J. Physiol. Gastrointest. Liver Physiol. 290: G577-582.

Sherman, P. M., Johnson-Henry, K. C., Yeung, H. P., Ngo, P. S., Goulet, J. and Tompkins, T. A. 2005. Probiotics reduce enterohemorrhagic Escherichia coli O157:H7- and enteropathogenic $E$. coli O127:H6-induced changes in polarized T84 epithelial cell monolayers by reducing bacterial adhesion and cytoskeletal rearrangements. Infect. Immunol. 73: 5183-5188.

Smith, H. W. 1965. Development of flora of alimentary tract in young animals. J. Pathol. Bacteriol. 90: 495.

Sommer, M. O., Dantas, G. and Church, G. M. 2009. Functional characterization of the antibiotic resistance reservoir in the human microflora. Science 325: 1128-1131.

Songer, J. G. and Anderson, M. A. 2006. Clostridium difficile: an important pathogen of food animals. Anaerobe 12: 1-4.

Stecher, B. and Hardt, W. D. 2008. The role of microbiota in infectious disease. Trends Microbiol. 16: 107-114.

Suau, A., Bonnet, R., Sutren, M., Godon, J. J., Gibson, G. R., Collins, M. D. and Dore, J. 1999. Direct analysis of genes encoding 16S rRNA from complex communities reveals many novel molecular species within the human gut. Appl. Environ. Microbiol. 65: 4799-4807.

Surawicz, C. M. 2009. Reining in recurrent Clostridium difficile infection - who's at risk? Gastroenterology 136: 1152-1154.

Suzuki, K., Meek, B., Doi, Y., Muramatsu, M., Chiba, T., Honjo, T. and Fagarasan, S. 2004. Aberrant expansion of segmented filamentous bacteria in IgA-deficient gut. Proc. Natl. Acad. Sci. USA 101: 1981-1986.

Talham, G. L., Jiang, H. Q., Bos, N. A. and Cebra, J. J. 1999. Segmented filamentous bacteria are potent stimuli of a physiologically normal state of the murine gut mucosal immune system. Infect. Immunol. 67: 1992-2000.

Thompson-Chagoyán, O. C., Maldonado, J. and Gil, A. 2005. Aetiology of inflammatory bowel disease (IBD): Role of intestinal microbiota and gut-associated lymphoid tissue immune response. Clin. Nutr. 24: 339-352.

Tlaskalova-Hogenova, H., Stepankova, R., Hudcovic, T., Tuckova, L., Cukrowska, B., Lodinova-Zadnikova, R., Kozakova, H., Rossmann, P., Bartova, J., Sokol, D. and others. 2004. Commensal bacteria (normal microflora), mucosal immunity and chronic inflammatory and autoimmune diseases. Immunol. Lett. 93: 97-108.

Underwood, M. A., Salzman, N. H., Bennett, S. H., Barman, M., Mills, D. A., Marcobal, A., Tancredi, D. J., Bevins, C. L. and Sherman, M. P. 2009. A randomized placebo-controlled comparison of 2 prebiotic/probiotic combinations in preterm infants: impact on weight gain, intestinal microbiota, and fecal short-chain fatty acids. J. Pediatr. Gastroenterol. Nutr. 48: 216-225.

Vanderpool, C., Yan, F. and Polk, D. B. 2008. Mechanisms of probiotic action: Implications for therapeutic applications in inflammatory bowel diseases. Inflamm. Bowel Dis. 14: 1585-1596.

Winkler, P., Ghadimi, D., Schrezenmeir, J. and Kraehenbuhl, J. P. 2007. Molecular and cellular basis of microflora-host interactions. J. Nutr 137 (3 Suppl 2): 756S-772S.

Yoshioka, H., Iseki, K. and Fujita, K. 1983. Development and differences of intestinal flora in the neonatal-period in breastfed and bottle-fed infants. Pediatrics 72: 317-321. 